\title{
Form and Function of Carrying Tools in Traditional and Contemporary Culture
}

\author{
Hendriana Werdhaningsih \\ Design Department, Paramadina University
}

\begin{abstract}
The Javanese Traditional Carrying Tools are categorized into two kinds based used of materials: anyaman made of woven bamboo or rattan and the other was made of cloth. The Traditional Javanese Carrying Tools that were made of bamboo/ rattan is actually a kind of container with different shapes. The types of goods that were brought was related to the shapes of the containers, demonstrate the type of interactions between the carrier and the goods. The Traditional Carrying Tools made of cloth have the flexibility in terms of being the containers of the carried goods. Selendang is used to carry goods, including the bamboo/ rattan containers and to carry babies. It can be used rumpled and straightened depends on the technical needs of carrying tools preferred by the user. In contemporary culture, the form and design of carrying tools more less construct by fashion and trends besides those practical used. Some product are being 'classic', some other are being 'fad'. Both products, traditional and contemporary have their own style, uniqueness, and own context. Analyzing both in design point of view is important as evaluation process, to finding new problems that will be starting point to create new products. Indonesia is well known for its abundant richness in traditions, which include the culture, the art, and the traditional products. Such treasure of traditions can inspire the development and invention of various kinds of artwork and current products.
\end{abstract}

Keywords: Carrying tools; contemporary; culture; fashion; traditional.

\section{$1 \quad$ Introduction}

Carrying tool is a handling device, to carry things of, were it is used by people for traveling purpose. Carrying tool is everyday thing product that supports people's activities and it has unique feature that is physically closed to the user in order to handling as well as close attachment to the human body. There-fore its function and form have close relation to the user's activities, and furthermore their social culture. Due to its unique characteristic of carrying tools that relate to its particular culture, thus this article would like to discuss the both culture in seeing this particular product from its form and function. This article will discuss general view of carrying tools in contemporary world and either way, Javanese culture was taken as an example of discussing the traditional one. 


\section{Carrying Tools in Contemporary Culture}

In contemporary life, carrying tools products are mostly consist of bag, including handbag, mailbag, strap, backpack, suitcase, trunk, valise, wallet, billfold, purse, and pouch, and cart, such as wagon, dray, wheelbarrow, trolleys and handcart. All these variant of carrying tools are similar throughout the world, as they are part of global culture of man made products.

In addition, the functions of carrying tools were mostly expressed by their volume. Wallet and bill fold are tiny folded pouch which have enough space, only to carry money and cards. Purse and pouch, have bigger room to place and carry money, cards and sometimes cell phone. Handbag and portmanteau are bigger enough to place and carry more money, cards, cell phone, simple cosmetics and comb. Other bags such as mailbag, strap bag, back-pack, suitcase, varies in volume depend on its distinct purpose, they can carry more things as much as 50 liters, and trunk can even carries more than 50 liters.

In general, bags have closed form, made by different kinds of material such as leather, fabric, artificial leather, plastics and metals. Many bags were made of more than one material. Different materials were used for outside and inside lining, for body and handle or strap, as well as uses of different materials to consider aesthetical purpose. The use of material depends on material characteristic such as durability of weight, water resistance, and flexibility, aesthetic appearance and so on.

Cart as functional product were formed to support people for easy transporting goods, especially for difficult product to carry by hand. Cart design was developed in term of function, technology and material invention. General cart was divided into two categories, with and without human power. Furthermore, the invention of technology replaced animal power such horses with machine power. In order to carrying tools in distance, propelled cart was used to carry longer distance, while human power cart was used to carry shorter trip. In term of function, some carts were designed as multipurpose device, some others for special utilities, for example, cart or trolley that was designed for supermarket, for suitcases and trunks in airport, for hospital devices, etc. Cart with multipurpose usability usually have simple and open form, so that those have flexibility to carry kinds of shapes. Cart for special purpose usually have special form, which fits with kinds carries. Cart, excluded cars, uninfluenced by fashion, but developed more for practical function. 
Bags in contemporary culture not solely employed as carrying device. On the other hand, bags were also part of fashion and lifestyle product. Bags designs were influenced by style and lifestyle of specific society. As Caroline Cox mention in her books Bags that the handbags is truly modern phenomenon: A bewitching accessory that has ability to shift its shape every nuance of fashion. In contemporary life, kinds of style and lifestyle exist. Bags also exist to support needs of each. Some bags design become classic and some other fads [1].

In Western culture, bags for woman were emerged from the needs of carrying things since women were liberated from just domestic matters and become have more freedom to choose their live. Therefore, they need tools to carry their necessities and many other things. Since its merge, bags are very close with fashion. Room inside bags have to able to accommodate all things they carries; fragile cosmetics and perfume bottle, sharp side keys, busy cell phone, many coins, money and bills. Outside bags have to represent the appearance the user's preferences. Shape, color and material should be match with out-fits, occasions, and each personality, besides its utilities to carry things. In extreme bags for some women, become must-have product, for not only the elite but also the ordinary women. As Stuart Vevers, the British Fashion Council's Accessory Designer of the Year 2006 winner, comments: "A few years ago, designer or luxury goods were only for elite, but now I get on the bus in Hackney and see ladies with genuine Mulberry bags that I know cost $600 \mathrm{fr} "$.

Five years ago, people were used to have high-street out-fits and high-street bags; now they only have high-street outfit but the others are designer bags and shoes. The industry now is huge, and there is no turning back, once people have getting used to with the quality, they will stick with it for long period of time. In contemporary culture, designers in any layers create bags as unique as can be, placed bags as consumer goods that may attract people to buy it. Some designers sell their brand; some designers sell innovations in durability, some designers sell other values.

Bag design was influenced by arts, social and cultural movements. Tiny wrist bag influenced by cubism, streamline shape of the clutch bag reflected the modernity of art deco, bag also adopt surrealism ideas. Strap bag and backpack come from military utilities to variant of nonmilitary bags in contemporary culture. Hippie movement rose or brought up tote bags, which also common nowadays. Millions variant from those kinds of bags can find in contemporary life. The used of bags depends on occasions, place to go, things to carry, and users personality. A 'bohemian-eco minded' style people goes to the market with one big full color tote made by woven textile which can carry all his/her things. They goes to party carries small pouch, with the similar woven textile. An 'outdoor' style people carry backpack everywhere. A 'military' style people every 
variant of military bags in different occasions. A 'scholar' style people carry big laptop bags. In addition, an 'In Style' people use designer bags, original or fake one, everywhere they go. Bags become part of self-expression, or selfstatement. Bags in fashion formed for the sake of their looks, sometimes unconnected to what carry in-side.

\section{Traditional Carrying Tools: Case of Javanese Carrying Tools}

Nowadays, in Central Java, Jogjakarta and Surakarta traditional carrying tools are still being used for daily activities. For example, people use them to go to the markets, in rural area or even on the intercity road. Traditional way of carrying is common sight in the region. It is part of a distribution pattern during the past time in Java, i.e.: gulungan / mapadati (carriages pulled by animals as means of transportation), tandu (specifically used to carry people, lifted by some people and then rested on their shoulders), atitih (carrying tools placed on horses' backs), pikulan and gendhong (carrying tools using a long cloth hanged on a person's back) (Figure 1).
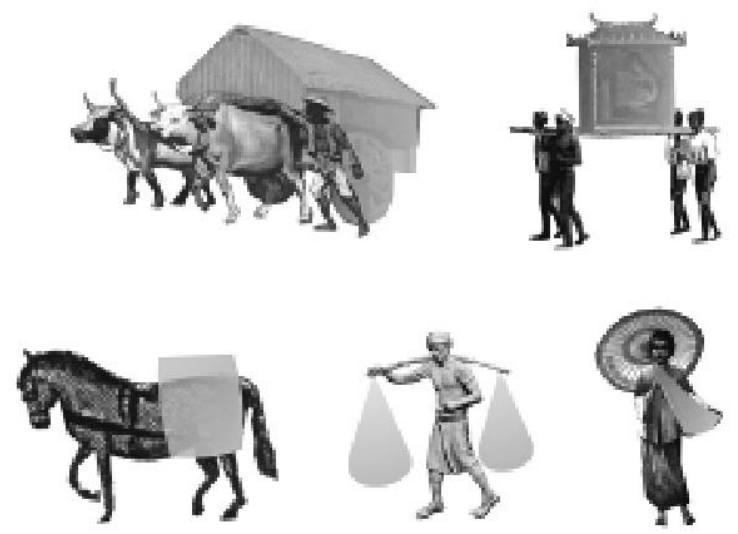

Figure 1 Distribution patterns during the past time in Java.

The pictures were also shown of traditional distribution patterns from the lower class in Javanese culture. Similar with other traditional civilization, traditional Javanese people is divided into two classifications; wong gedhe (the high-class) and wong cilik (the lower-class). Wong gedhe people did not carry things; wong cilik did that for them. Wong cilik carried wong gedhe with tandu. Wong cilik who was working for wong gedhe carried wong gedhe's baby.

Wong gedhe and wong cilik are not really mentioned nowadays. Traditional carrying tools can be used by everyone from any social class. Due to the 
emerging of new technology, traditional carrying tools were transformed to different mode. Tandu and atatih, were no longer used, and madapati and pikulan are now rare. Atatih was transformed into kronjot which was replaced by bicycle and motorcycle, and tandu was replaced by cars.

The traditional Javanese carrying tool was categorized into two kind based of materials: the first one was anyaman (woven) made of bamboo/ rattan and the other one was made of cloth. The bamboo/ rattan is categorized into carried without any other tools, carried with the use of cloth, carried with the use of a long stick rested on (a) shoulder(s), and carried by a two-wheeled vehicle . Traditional carrying tools made of cloth consist of selendang (pashmina- like cloth) and ules. The traditional carrying tools made of cloth have the flexibility in terms of being containers of the carried goods. Selendang uses to carry goods, including the bamboo/ rattan containers and to carry babies. It can be used rumpled and straightened depends on the technical needs of carrying tools preferred by the user. Selendang for carrying things is lurik. Batik with floral pattern used for carrying babies. Lurik has more durability than batik. Batik has softer texture and their floral pattern symbolized fertility.

The Javanese traditional bamboo/rattan carrying tools is kind of container with different shapes. The bamboo/ rattan containers are categorized based on their shapes into: wide-opened, opened, semi-closed, and closed. There are some relations between the shape and the type of carried goods. The wide-opened containers such as tambir and tampah, with tight anyaman were used to handle foods and to dis-play ready-to-eat foods. Opened-containers with loose anyaman, bronjong, were used to carry vegetables. The opened-containers, with tight anyaman, tenggok and kronjot, were used to carry any kinds of goods. The semi-closed containers with tight anyaman, tenggok with tambir, were used to serve foods and some ingredients. The closed-containers with tight or loose anyaman, tenong, kepis, kisan and variants of kronjot, were used to carry only one type of goods: fresh traditional snacks, live fish, or live chicken. The types of goods were related to the shapes of the containers, also the type of interactions between the carrier and the goods, both operational functions and the views towards the abstract values of the carried goods.

Similar with bags in Western culture in the past, there was also a differentiation in the traditional Javanese carrying tools that is based on gender/ sex of user. It is the biological of human anatomy, in which the different between shapes of male and female body parts. Males' shoulders tend to be wider and flatter that is suitable to shoulder carry, while females' shoulders tend to have narrower dropping curve that is less likely suitable to hold shoulder carry. The females hips are wider than males that made the activity of menggendhong (Javanese way of carrying called gendhong) is likely suitable for females than males. 
In addition, the traditional Javanese culture distinguishes males and females duty based on their social responsibility. The males are responsible of the duties in the social surrounding environment while females are responsible in the domestic areas. This made the carrying products to be different. Gendhongan is typical female carrying tools (Figure 2), and pikulan is typical male carrying tools (Figure 3).

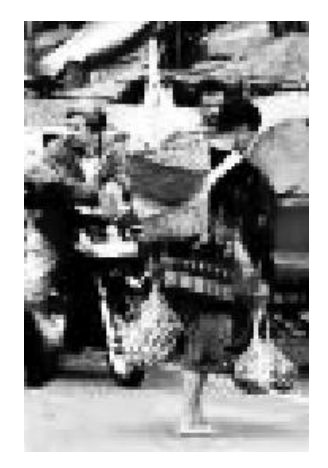

Figure 2 Gendhongan is typical female carrying tools.

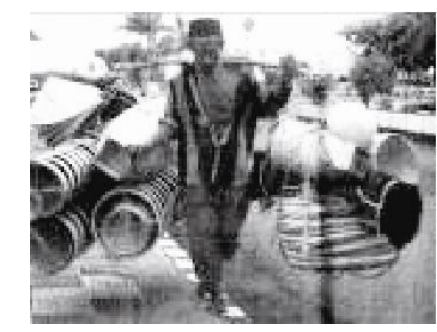

Figure 3 Pikulan is typical male carrying tools.

In bereavement duties for example, women was assigned for one gendhongan and male for one pikulan. Up until now, it is very uncommon for male to carry things with gendhongan, or female to carry things with pikulan. The unisex traditional carrying tool is kronjot, which can be employed by anyone who can ride a bike or motorcycle. Male nowadays prefer to use kronjot than pikulan. Women are still using gendongan as carrying tools. Selendang as tools for nggendhong (carrying), are similar to bags for women in Western culture. Selendang is more likely very close to women, as extension part of her body. Selendang is always lying on her shoulder as empty bag, ready to use for carrying things (Figure 4). Some women used an end of selendang to wrap her money in (Figure 5). Sometimes selendang used to protect her head from sun ray, wind or shower rain (Figure 6). 


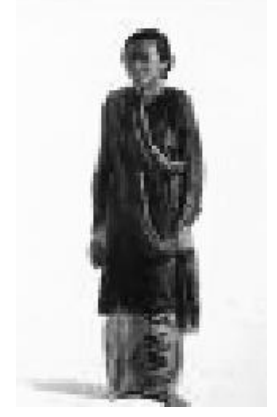

Figure 4 Women with selendang on her shoulder, a painting from Frans Lebret, 1863.

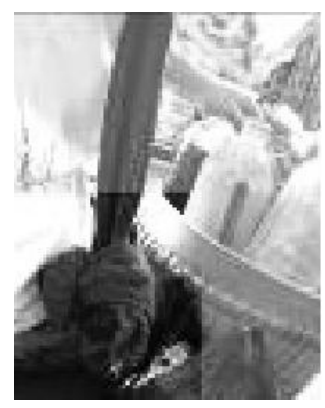

Figure 5 End of selendang to wrap money.

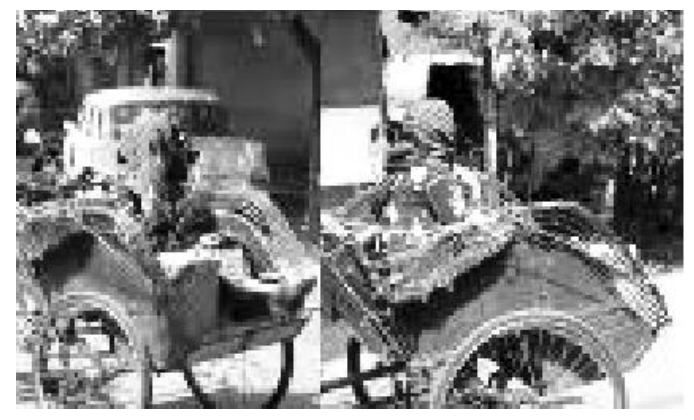

Figure 6 Selendang used for sun, rain and wind protection.

\section{Traditional Idea in Contemporary Life}

Both carrying products in traditional and contemporary cultures have their own style, uniqueness, and own context. Analyzing both in design point of view is important as evaluation process, to finding new problems that will be used as starting point to create new products. 
As happened in the development of baby carriers design. In the Western society, on-the-body baby carrying just started to known in the 60's with the advent of the structured soft pack. In the early 70's, in Germany, the wrap was reintroduced. In 1986, the ring sling was invented and well populated. On-thebody baby carrying established in many cultures, including Javanese wong cilik people, for centuries. Chinese mei tai, which has been around for centuries, is become popular in mid-2003 after being modernized with padding and other adjustments.

Indonesia is well known for its abundant richness in traditions, which include culture, art, and traditional products. Such treasure of traditions may inspire the development and invention of various kinds of art-work and current products. Moreover, the design development based on Indonesian traditions can be used as a powerful weapon in the vast competition of design in the world today. The thorough understanding of the principles of traditions is one of the most important things for a designer in order to utilize it as a source of inspiration.

\section{References}

[1] Cox, Caroline. 2007. Bags, Aurum Press Ltd. London. 